Innowacje w Pielęgniarstwie i Naukach o Zdrowiu

$2(1) / 2016$

ISSN: 2451-1846

DOI: http://dx.doi.org/10.21784/IwP.2016.008

Joanna Węglarska ${ }^{1}$, Maria Posłuszna-Owcarz ${ }^{1}$

${ }^{1}$ Kujawska Szkoła Wyższa we Włocławku

\title{
Postawy pielęgniarek wobec osób zarażo- nych wirusem HIV i chorych na AIDS
}

\section{Attitudes of nurses towards patients with HIV and AIDS}

\section{Streszczenie}

Ministerstwo Zdrowia szacuje, że w Polsce liczba zakażonych wirusem HIV może sięgać około 35 tysięcy osób (2014 rok). Mimo coraz szerszej edukacji społecznej postawy wobec osób seropozytywnych są nadal bardzo zróżnicowane. Problem ten dotyczy także pracowników ochrony zdrowia.

Celem badań było poznanie postaw pielęgniarek, studiujących Pielęgniarstwo II stopnia na WSHE we Włocławku, pracujących w różnych placówkach ochrony zdrowia, wobec pacjentów zarażonych wirusem HIV i chorych na AIDS.

Badania przeprowadzono na grupie 97 pielęgniarek, w oparciu o kwestionariusz anonimowej ankiety konstrukcji własnej, na terenie Wyższej Szkoły Humanistyczno-Ekonomicznej we Włocławku ( obecnie Kujawskiej Szkoły Wyższej we Włocławku).

Podsumowując wyniki badań można stwierdzić, że poczucie zagrożenia i lęku przed zakażeniem HIV wśród badanych pielęgniarek studiujących na WSHE we Włocławku było dość wysokie. Badania dowiodły, że wiek 
personelu pielęgniarskiego, stan cywilny, staż pracy, stopień wyposażenia stanowiska pracy w środki ochrony indywidualnej oraz w procedurę postępowania po ekspozycji zawodowej, mają wpływ na postawę wobec pacjentów seropozytywnych, natomiast nie stwierdzono takiej zależności w przypadku miejsca pracy respondentów. Również dowiedziono, że na postawę wpływa posiadana wiedza, natomiast nie wpływają posiadane przez pielęgniarki dodatkowe kwalifikacje.

Choć większość respondentów deklarowała pozytywne i obojętne nastawienie do pacjentów seropozytywnych, to jednak konkretne postawy wynikające $\mathrm{z}$ ankiety budzą niepokój autorów. Można wnioskować, że główną przyczyną tego stanu może być, pomimo posiadanej wiedzy na średnim poziomie z zakresu HIV/AIDS, mała liczba odbytych przez respondentów profesjonalnych szkoleń prowadzonych przez specjalistów posiadających wiedzę w oparciu o doświadczenie w tej dziedzinie. Możliwość kontaktowania się pielęgniarek co jakiś czas z kompetentnymi szkoleniowcami, może odegrać znaczącą rolę w kształtowaniu postaw i zachowań zarówno wśród pielęgniarek, jak i pozostałych pracowników ochrony zdrowia.

\section{Abstract}

Polish Ministry of Health estimates that the number of HIV positive people may be reaching 35 thousand. Despite widespread educational campaign, attitudes towards the HIV positive are still varied. The problem also refers to health service employees

The aim of the study was to examine attitudes of nurses, the second degree nursing students at the University of Humanities and Economics in Wloclawek (UHE), employed by various health care institutions, towards HIV infected patients and patients with AIDS.

The studies were carried out in a group of 97 nurses, based on our own anonymous survey questionnaire developed by the authors of the study, at the University of Humanities and Economics in Wloclawek (Cuiavian Uniwersity in Wloclawek).

The study results demonstrate that the feeling of threat and of fear of becoming infected with HIV is quite strong among the nursing students at the UHE in Wloclawek. The study has proved that the nursing staff's age, marital status, years of service, and the availability of personal protective equipment at the workplace as well as post-exposure procedures at work have the influence on the attitude towards HIV-positive patients, whereas 
such an impact was not identified in reference to the workplace of the respondents. It has been also proved that the attitudes are strongly affected by the level of knowledge demonstrated by nurses, in contrast nurses' additional qualifications have no effect in that matter.

Although most respondents declared positive and indifferent attitude towards HIV/AIDS patients, how ever some specific attitudes resulting from the survey arise authors' concern. It can be concluded that the main cause of this condition can be, despite their knowledge of the medium level of the scope of HIV/AIDS, their participation in an insufficient number of professional trainings carried out by experts with knowledge based on experience in that field. The ability for nurses to contact from time to time competent trainers, can play a significant role in shaping the attitudes and behaviours among nurses as well as among other health service system employees.

Słowa kluczowe: HIV, AIDS, postawy

Key words: HIV, AIDS, attitudes

\section{Wstęp}

Trwoga przed AIDS i jej nieuleczalnością oraz publiczne piętno, jakie jej towarzyszy, wskutek braku wiedzy społeczeństwa, wciąż budzą strach. Zdarza się, że w obliczu AIDS nadal zawodzą kodeksy etyczne i moralne, obserwowane nie tylko wśród społeczeństwa, ale również w środowisku medycznym.

Negatywne emocje w stosunku do zakażonych wirusem HIV pojawiały się nie tylko w postawach szerszego społeczeństwa, ale także w ich najbliższym otoczeniu. Chorzy, niejednokrotnie wyrzucani z domów rodzinnych, w swojej dramatycznej sytuacji zdrowotnej byli pozbawiani zarówno miejsca do życia jak i psychicznego wsparcia $[1,2,3]$.

Postawy tego typu, wraz z towarzyszącym im silnym lękiem, można było zaobserwować także w środowisku medycznym. Lekarze, pielęgniarki i studenci obawiali się kontaktów z osobami zakażonymi i chorymi, a także dość często obce było im współczucie, serdeczność i pomoc - tak potrzebne w pracy z chorymi ludźmi. Przyznanie się do 
faktu nosicielstwa pozbawiało często możliwości skorzystania z pomocy stomatologa, czy odbycia porodu w warunkach szpitalnych, a było to rezultatem nieznajomości dróg przenoszenia choroby. Personel ochrony zdrowia nie był przygotowany na kontakt z osobami zakażonymi. Problem stanowił choćby sposób w jaki należy powiadomić zakażoną osobę o wynikach testu, który w owym czasie wydawał się niemal jednoznaczny z wyrokiem śmierci $[4,5]$.

Dziś wydawałoby się, że społeczeństwa wielu krajów solidaryzują się z osobami żyjącymi z HIV, a pracownicy ochrony zdrowia są odpowiednio przeszkoleni i posiadają wiedzę o metodach pracy z pacjentami HIV dodatnimi. Niestety są to zwykle pozory. Choć agresja jako reakcja na obecność osoby zakażonej nie jest już częstym zachowaniem, to jednak nadal spotykana jest niechęć i strach przed kontaktami z tą grupą pacjentów. Strach jest rezultatem nieodpowiedniego przygotowania merytorycznego pracowników personelu pielęgniarskiego i wypływa $\mathrm{z}$ autentycznej obawy o utratę własnego zdrowia.

Najwięcej udokumentowanych i prawdopodobnych zakażeń zawodowych HIV na świecie stwierdzono u pielęgniarek i położnych. To właśnie pielęgniarki najczęściej używają igieł do iniekcji, nie zawsze przestrzegając podstawowych zasad bezpieczeństwa. Dane wskazują, że ryzyko rozwoju zakażenia HIV w następstwie ekspozycji zawodowej wynosi $0,3 \%$ co stanowi 3 przypadki na 1000 ekspozycji. Jak dotąd w Polsce nie odnotowano przypadku poekspozycyjnego zakażenia HIV. Ciągła kontrola realizacji zasad postępowania zwiększa bezpieczeństwo personelu i pacjentów oraz sprawia, że bieżąca opieka pielęgniarska realizowana jest bez zagrożeń. Stałe dokształcanie personelu medycznego, zdobywanie aktualnej wiedzy w zakresie HIV i AIDS, pomaga zmniejszyć stres związany z pracą, a zarazem wpływa na kształtowanie etycznych postaw wobec pacjentów seropozytywnych $[1,2,6,7]$

Celem głównym niniejszych badań przeprowadzonych na podstawie autorskiej ankiety, uczyniono poznanie postaw pielęgnia- 
rek studiujących na kierunku Pielęgniarstwo II stopnia na WSHE we Włocławku, pracujących w różnych placówkach ochrony zdrowia, wobec pacjentów zarażonych wirusem HIV i chorych na AIDS. Problem główny ujęto w formie pytania, które brzmi; Czy postawy pielęgniarek/pielęgniarzy wobec pacjentów zakażonych wirusem HIV/chorych na AIDS, są zgodne z zasadami kodeksu etyki oraz standardami zawodowymi?

\section{Materiał i metody}

Mając na uwadze realizację obranego celu, posłużono się $\mathrm{w}$ badaniach metodą sondażu diagnostycznego z techniką ankietowania. Do badań wykorzystano autorską ankietę. Gromadzeniu danych posłużył kwestionariusz ankiety. Kwestionariusz zawierał 36 pytań, których celem było uzyskanie odpowiedzi na wyłonione problemy badawcze.

Badaniu poddana została grupa 97 pielęgniarek losowo wybranych spośród 120 studiujących czwarty semestr na kierunku pielęgniarstwo, studia II stopnia na WSHE we Włocławku (obecnie Kujawska Szkoła Wyższa we Włocławku). Badana grupa pielęgniarek w swojej codziennej pracy zajmuje się świadczeniem usług medycznych w różnych placówkach ochrony zdrowia na terenie Polski.

\section{Wyniki}

Wśród respondentów najliczniejszą grupę stanowiły pielęgniarki w wieku pomiędzy 36 a 50 rokiem życia - 58,7\%. Następną, pielęgniarki między 21 a 35 rokiem życia - 22,7\%. Najmniej liczebną grupą osób badanych były pielęgniarki posiadające 51 lat i więcej $18,6 \%$. Biorąc pod uwagę stan cywilny, pielęgniarki zamężne stanowiły $67,0 \%$ badanej populacji, stanu wolnego było 33,0\% badanych. Wśród pielęgniarek uczestniczących w badaniu 59,8\% zatrudnionych było w szpitalu, $19,6 \%$ w podstawowej opiece zdrowotnej oraz $20,6 \%$ pielęgniarek pracowało $\mathrm{w}$ innych placówkach ochrony zdrowia tj. dom pomocy społecznej, zakład opiekuńczo-leczniczy, żłobek, ośro- 
dek rehabilitacyjno-leczniczy, szpital uzdrowiskowy. Ze względu na okres pracy największą liczebnie grupę stanowiły pielęgniarki ze stażem 24-29 lat pracy - 23,7\%, następnie ze stażem 5 lat - 17,5\%, a 16,5\% - powyżej 29 lat pracy. Kolejne grupy stażowe to 6-11 lat $15,5 \%, 18-23$ lata $-14,4 \%$ oraz $12-17$ lat $-12,4 \%$ badanej populacji. Wszystkie pielęgniarki poddane badaniu posiadały wyższe wykształcenie zawodowe. Grupa pielęgniarek z dodatkowym wykształceniem stanowiła 17,5\% ankietowanych, w której to respondenci posiadali specjalizacje z pielęgniarstwa: chirurgicznego, zachowawczego, epidemiologicznego, ratunkowego, opieki długoterminowej, ale również studia wyższe np. pedagogiczne, humanistyczne, nauk politycznych, historia.

Spośród respondentów, 36,1\% uważało, że zakażeni HIV powinni pracować/uczyć się wraz ze zdrowymi, przeciwnego zdania było $43,3 \%$, a $20,6 \%$ nie wiedziało jakie stanowisko zająć w tej sprawie. Strach podczas kontaktów z pacjentem zarażonym HIV odczuwa $32,0 \%$ badanych pielęgniarek, 29,9\% odpowiedziało, że raczej odczuwa strach, $24,7 \%$ nie odczuwa strachu, a 13,4\% miało trudność $\mathrm{z}$ wyborem odpowiedzi.

Kontakt pozazawodowy z osobami żyjącymi z HIV miało 25,8\% respondentów, 54,6\% nie miało kontaktów, 19,6\% nie potrafiło odpowiedzieć, gdyż nie posiadało takiej wiedzy.

Za informowaniem w miejscu pracy/nauki o zakażeniu HIV opowiedziało się $64,9 \%$ respondentów, tylko $17,5 \%$ badanych pielęgniarek uważało, że nie należy informować, 17,5\% nie wiedziało, jakie stanowisko zająć. $Z$ kolei 40,2\% respondentów uznało, że mogłoby pracować z koleżanką seropozytywną na tym samym odcinku, 40,2\% - nie mogłoby, $18,6 \%$ badanych nie wiedziało jakie stanowisko zająć.

Respondenci zapytani o nastawienie do pacjentów seropozytywnych w 34,0\% odpowiedzieli, że mają nastawienie pozytywne, w 46,4\% badanych miało nastawienie obojętne, a 19,6\% pielęgniarek prezentowało nastawienie negatywne. 
Większość respondentów swoją wiedzę z zakresu zasad kodeksu etyki zawodowej oceniało na poziomie średnim - 53,6\%, $29,9 \%$ oceniło wysoko, $16,5 \%$ nisko. Spośród badanych pielęgniarek $53,6 \%$ odpowiedziało, że stosują się w pracy do przepisów kodeksu etyki zawodowej, 46,4\% raczej się stosuje, odpowiedzi negatywnych nie zarejestrowano.

Spośród objętych badaniem pielęgniarek, aż 52,6\% przyznało się, że ograniczało do minimum kontakty z pacjentami seropozytywnymi, $24,7 \%$ nie ograniczało kontaktów, a 22,7\% nie zdecydowało się jaką odpowiedź wybrać.

Analiza uzyskanych wyników pokazała, że aż 49,5\% pielęgniarek nie opiekowało się dobrowolnie pacjentami zarażonymi wirusem HIV, dobrowolnie opiekowało się 30,9\%, 19,6\% miało trudność z wyborem właściwej dla siebie odpowiedzi, co mogło oznaczać, że jest skłonność do opowiedzenia się za pierwszą grupą. Tylko $13,4 \%$ badanych respondentów chętnie podjęłoby pracę z pacjentami seropozytywnymi, 36,1\% niechętnie podjęłoby taką pracę, a 50,5\% pielęgniarek stwierdziło, że jest im to obojętne.

Zdecydowana większość pielęgniarek uczestniczących $\mathrm{w}$ badaniu, bo aż $84,5 \%$ uważała, że nie ma takiej przyczyny, która byłaby usprawiedliwieniem odmowy udzielenia medycznej pomocy osobie zakażonej wirusem HIV. Były też pielęgniarki (15,5\%), które twierdziły, że takie powody istnieją i jako uzasadnienia podały: brak środków ochrony indywidualnej, agresywność pacjenta, niewiedza ze strony personelu medycznego.

Pielęgniarki uczestniczące w badaniu, w większości tj. 59,8\%, oceniły swoją wiedzę w zakresie HIV/AIDS na poziomie średnim, 32,0\% na poziomie wysokim i 8,2\% na poziomie niskim.

Spośród respondentów, w szkoleniach specjalistycznych na temat HIV/AIDS kilka razy uczestniczyło 20,6\%, jeden raz brało udział $36,1 \%$ pielęgniarek, a $43,3 \%$ nigdy nie było na tego typu szkoleniu. 
Na pytanie czy w ostatnich latach w Polsce, liczba nowo rozpoznanych zakażeń HIV rośnie, prawidłowej odpowiedzi udzieliło $46,4 \%$ pielęgniarek, według $36,1 \%$ zakażenie HIV utrzymuje się na tym samym poziomie, natomiast $17,5 \%$ uważało, że liczba maleje.

Większość bo 51,5\% respondentów wybrało prawidłową odpowiedź wskazującą na to, że badania na obecność wirusa HIV wykonywane są bezpłatnie w punktach konsultacyjno-diagnostycznych, $35,1 \%$ odpowiedziało, że są anonimowe i bezpłatne $\mathrm{z}$ ważnym skierowaniem, 13,4\% uznało, że są bezpłatne tylko w poradniach podstawowej opieki zdrowotnej. Zakażony mężczyzna może posiadać zdrowe potomstwo, ale jest to uzależnione od prowadzonego leczenia i tak sformułowaną prawidłową odpowiedź podało $36,1 \%$ pielęgniarek. Z kolei $46,4 \%$ odpowiedziało, że mężczyzna może posiadać zdrowe potomstwo bez żadnych zależności, 15,4\% uważa, że mężczyzna seropozytywny nie może posiadać zdrowego potomstwa, aż 2,1\% odpowiedziało, że zawsze może posiadać zdrowe dzieci. Właściwą odpowiedź, iż nosicielka HIV będąca w ciąży nie zawsze przekazuje wirus swojemu dziecku i zależy to od prowadzonego przez nią leczenia oraz od postępowania położników podczas porodu, wybrało $56,7 \%$ respondentów. Natomiast według 30,9\%, wirus jest zawsze przekazywany oraz $12,4 \%$ respondentów odpowiedziało, że wirus nie jest przekazywany dziecku. Przeciwciała we krwi można wykryć w okresie od 6 tygodni do 3 miesięcy od zakażenia i tak sformułowanej prawidłowej odpowiedzi udzieliło $44,3 \%$ pielęgniarek, $22,7 \%$ uważało, że po 2 miesiącach, 18,6\%, że od 7 tygodni do 4 miesięcy oraz $14,4 \%$ pielęgniarek uznało, że od 10 tygodni do 3 miesięcy.

Swoje miejsce pracy pod względem ryzyka zakażenia HIV, respondenci w 44,3\% ocenili jako miejsce wysokiego ryzyka, 40,2\% jako miejsce średniego ryzyka oraz $15,5 \%$ jako miejsce niskiego ryzyka.

Miejsce swojej pracy pod względem wyposażenia w środki ochrony indywidualnej $26,8 \%$ respondentów oceniło w kategorii sze- 
rokiego zakresu, większość 52,6\% określiło wyposażenie w średnim zakresie, $20,6 \%$ oceniło $\mathrm{w}$ niewielkim zakresie.

Zdecydowana większość respondentów, bo $68,0 \%$ posiadała $\mathrm{w}$ miejscu pracy procedurę postępowania w przypadku ekspozycji zawodowej, nie posiadało procedury $17,6 \%$. Natomiast $14,4 \%$ pielęgniarek nie wiedziało, czy w miejscu pracy taka procedura istnieje.

Zestaw leków stosowanych w profilaktyce poekspozycyjnej w miejscu pracy posiadało tylko $26,8 \%$ respondentów, $53,6 \%$ nie posiadało, 19,6\% nie wiedziało, czy w miejscu pracy takie leki się znajdują.

Podczas wykonywania zabiegów medycznych, spokój i ostrożność zachowuje 71,2\% respondentów, nie zawsze zachowuje ostrożność 20,6\% , nie zachowuje ostrożności aż 8,2\% pielęgniarek.

Doświadczenie zawodowe z pacjentami seropozytywnymi posiadało $37,1 \%$ respondentów, 62,9\% pielęgniarek nie miało w swojej pracy zawodowej doświadczenia z osobami HIV (+).

Biorąc pod uwagę związek pomiędzy ograniczaniem do minimum kontaktów z pacjentami seropozytywnymi a deklarowanym nastawieniem pielęgniarek do tych pacjentów, z obliczeń otrzymano wartość statystyki $\chi^{2}=7,247$. Natomiast dla przyjętego poziomu istotności $\alpha=0,05$ i dla 4 stopni swobody odczytana z tablicy rozkładu $\chi^{2}$ wartość krytyczna wynosiła $\chi_{\alpha}{ }^{2}=9,488$. W związku z tym, iż wartość $\chi^{2}$ zawierała się poza obszarem krytycznym, gdyż $\chi^{2} \leq \chi_{\alpha}{ }^{2}$, to nie było podstaw do odrzucenia hipotezy $\mathrm{H}_{0}$ o niezależności badanych cech. Oznacza to, iż nie potwierdzono związku pomiędzy ograniczaniem kontaktu z pacjentami seropozytywnymi przez pielęgniarki, a ich nastawieniem do pacjentów HIV (+). Hipotezę mówiącą, iż ogólna postawa pielęgniarek/pielęgniarzy do osób zakażonych wirusem HIV jest negatywna, odrzucono, ponieważ nie została ona potwierdzona powyżej omówioną hipotezą szczegółową. Analiza deklarowanego nastawienia pielęgniarek do osób seropozytywnych wskazywała, iż tylko niespełna $20 \%$ badanych cechowało negatywne nastawienie, natomiast pozostali byli ustosunkowani obojętnie lub pozytywnie. Deklarowane przez 53\% respondentów ograniczanie kontaktów 
z pacjentami seropozytywnymi, może świadczyć o tym, że postawa badanej populacji wobec pacjentów zakażonych wirusem HIV może ograniczać dostęp tych chorych do opieki pielęgniarskiej.

Analizując związek pomiędzy nastawieniem do pacjentów seropozytywnych a wiekiem pielęgniarek, z obliczeń otrzymano wartość statystyki $\chi^{2}=10,684$. Natomiast dla przyjętego poziomu istotności $\alpha=0,05$ i dla 4 stopni swobody odczytana z tablicy rozkładu $\chi^{2}$ wartość krytyczna wynosiła $\chi_{\alpha}{ }^{2}=9,488$. W związku z tym, iż wartość $\chi^{2}$ zawierała się w obszarze krytycznym, gdyż $\chi^{2} \geq \chi_{\alpha}{ }^{2}$ to hipotezę $\mathrm{H}_{0} \mathrm{O}$ niezależności należało odrzucić. Oznaczało to występowanie zależności między wiekiem pielęgniarek i ich nastawieniem do pacjentów seropozytywnych. Na podstawie badania można było stwierdzić, że respondenci najmłodsi, czyli w wieku 21-35 lat, stanowili 22,7\%, z czego połowa tj. 11,3\% deklarowała pozytywne nastawienie do osób seropozytywnych, 4,1\% obojętne nastawienie, 7,2\% negatywne. Pielęgniarki w wieku 36-50 lat stanowiły najliczniejszą grupę 58,8\% respondentów, spośród której tylko 15,5\% deklarowało pozytywne nastawienie, 34,0\% obojętne oraz 9,3\% negatywne nastawienie. Pielęgniarki w wieku 51 lat i więcej stanowiły grupę najmniej liczną $18,8 \%$, deklarującą w $7,2 \%$ nastawienie pozytywne, w $8,2 \%$ nastawienie obojętne oraz 3,1\% nastawienie negatywne.

Analizując związek pomiędzy nastawieniem do pacjentów seropozytywnych a stanem cywilnym pielęgniarek, z obliczeń otrzymano wartość statystyki $\chi^{2}=6,669$. Natomiast dla przyjętego poziomu istotności $\alpha=0,05$ i dla 2 stopni swobody odczytana z tablicy rozkładu $\chi^{2}$ wartość krytyczna wynosiła $\chi_{\alpha^{2}}=5,991$. W związku z tym, iż wartość $\chi^{2}$ zawierała się $w$ obszarze krytycznym, gdyż $\chi^{2} \geq \chi_{\alpha}{ }^{2}$ to hipotezę $\mathrm{H}_{0}$ o niezależności należało odrzucić. Oznaczało to występowanie zależności między stanem cywilnym pielęgniarek a ich nastawieniem do pacjentów seropozytywnych. Zamężnych pielęgniarek uczestniczących w badaniu było $67,0 \%$, z czego pozytywne nastawienie do pacjentów seropozytywnych deklarowało 17,5\%, obojętne $33,0 \%$, negatywne $16,5 \%$. Pielęgniarek wolnego stanu cywilnego było 
$33,0 \%$, z czego 16,5\% deklarowało pozytywne nastawienie, 13,4\% obojętne, 3,1\% negatywne.

Analizując związek pomiędzy nastawieniem do pacjentów seropozytywnych a miejscem pracy pielęgniarek, z obliczeń otrzymano wartość statystyki $\chi^{2}=3,669$. Natomiast dla przyjętego poziomu istotności $\alpha=0,05$ i dla 4 stopni swobody odczytana z tablicy rozkładu $\chi^{2}$ wartość krytyczna wynosiła $\chi_{\alpha}{ }^{2}=9,488$. W związku z tym, iż wartość $\chi^{2}$ zawierała się poza obszarem krytycznym, gdyż $\chi^{2} \leq \chi_{\alpha}{ }^{2}$ to nie było podstaw do odrzucenia hipotezy $\mathrm{H}_{0}$ o niezależności badanych cech. Oznaczało to, iż nie można dowieść wpływu miejsca pracy pielęgniarek na ich nastawienie w stosunku do pacjentów seropozytywnych.

Badając związek pomiędzy nastawieniem do pacjentów seropozytywnych a stażem pracy pielęgniarek, z obliczeń otrzymano wartość statystyki $\chi^{2}=16,737$. Natomiast dla przyjętego poziomu istotności $\alpha=0,05$ i dla 4 stopni swobody odczytana z tablicy rozkładu $\chi^{2}$ wartość krytyczna wynosiła $\chi_{\alpha}^{2}=9,488$. W związku z tym, iż wartość $\chi^{2}$ zawierała się $w$ obszarze krytycznym, gdyż $\chi^{2} \geq \chi_{\alpha}^{2}$ to hipotezę $\mathrm{H}_{0}$ o niezależności należało odrzucić. Oznaczało to występowanie zależności między stażem pracy pielęgniarek a ich nastawieniem do pacjentów seropozytywnych. W kwestionariuszu ankiety staż pracy prezentowany był w pięciu grupach, jednak do obliczeń statystycznych ograniczono do trzech. Respondenci ze stażem 5-11 letnim, stanowili 32\% badanej populacji, spośród której, 17,5\% deklarowało pozytywne nastawienie do osób seropozytywnych, 11,3\% obojętne, $3,1 \%$ negatywne. Respondenci z 12-23 letnim stażem pracy stanowili $27,8 \%$, z czego 11,3\% deklarowało pozytywne nastawienie, 9,3\% obojętne, 7,2\% negatywne. Respondenci od 24 letniego stażu w górę, byli najliczniejszą grupą stanowiącą 40,2\%, z czego pozytywne nastawienie deklarowało tylko 5,2\% pielęgniarek, obojętne $25,8 \%$, negatywne $9,3 \%$.

Badając związek pomiędzy nastawieniem do pacjentów seropozytywnych a dodatkowym wykształceniem pielęgniarek, z obliczeń 
otrzymano wartość statystyki $\chi^{2}=2,551$. Natomiast dla przyjętego poziomu istotności $\alpha=0,05$ i dla 2 stopni swobody odczytana z tablicy rozkładu $\chi^{2}$ wartość krytyczna wynosiła $\chi_{\alpha}{ }^{2}=5,991$. W związku $\mathrm{z}$ tym, iż wartość $\chi^{2}$ zawierała się poza obszarem krytycznym, gdyż $\chi^{2}$ $\leq \chi_{\alpha}{ }^{2}$ to nie było podstaw do odrzucenia hipotezy $\mathrm{H}_{0}$ o niezależności badanych cech. Oznacza to, iż nie można było dowieść wpływu dodatkowego wykształcenia pielęgniarek na ich nastawienie w stosunku do pacjentów seropozytywnych.

Analizując związek pomiędzy wyposażeniem stanowiska pracy w środki ochrony indywidualnej a nastawieniem pielęgniarek do pacjentów seropozytywnych z obliczeń otrzymano wartość statystyki $\chi^{2}=14,915$. Natomiast dla przyjętego poziomu istotności $\alpha=0,05$ i dla 4 stopni swobody odczytana z tablicy rozkładu $\chi^{2}$ wartość krytyczna wynosi $\chi_{\alpha}{ }^{2}=9,488$. W związku z tym, iż wartość $\chi^{2}$ zawierała się w obszarze krytycznym, gdyż $\chi^{2} \geq \chi_{\alpha}^{2}$ to hipotezę $\mathrm{H}_{0}$ o niezależności należało odrzucić. Oznaczało to występowanie zależności między wyposażeniem stanowiska pracy w środki ochrony indywidualnej, a nastawieniem pielęgniarek do pacjentów seropozytywnych. Spośród $26,8 \%$ respondentów o pozytywnym nastawieniu do pacjentów seropozytywnych, 14,4\% oceniło wyposażenie swojego miejsca pracy w środki ochrony indywidualnej w szerokim zakresie, 13,4\% w średnim zakresie, 6,2\% w niskim zakresie. Spośród 46,4\% respondentów o obojętnym nastawieniu do pacjentów seropozytywnych tylko 4,1\% oceniło wyposażenie swojego miejsca pracy w szerokim zakresie, 32,0\% w średnim zakresie, 10,3\% w niskim zakresie. Spośród 19,6\% respondentów z negatywnym nastawieniem, 8,3\% oceniło wyposażenie swojego miejsca pracy w szerokim zakresie, w średnim 7,2\% w niskim zakresie 4,1\%.

Analizując związek pomiędzy wyposażeniem stanowiska pracy w procedurę postępowania po ekspozycji zawodowej, a nastawieniem do pacjentów seropozytywnych, z obliczeń otrzymano wartość statystyki $\chi^{2}=11,677$. Natomiast dla przyjętego poziomu istotności $\alpha$ $=0,05$ i dla 4 stopni swobody odczytana $\mathrm{z}$ tablicy rozkładu $\chi^{2}$ wartość 
krytyczna wynosiła $\chi_{\alpha}^{2}=9,488$. W związku z tym, iż wartość $\chi^{2}$ zawierała się $\mathrm{w}$ obszarze krytycznym, gdyż $\chi^{2} \geq \chi_{\alpha}{ }^{2}$ to hipotezę $\mathrm{H}_{0} \mathrm{O}$ niezależności należało odrzucić. Oznaczało to występowanie zależności między istnieniem procedury postępowania w przypadku ekspozycji zawodowej na zakażenie HIV, HBV, HCV a nastawieniem pielęgniarek do pacjentów seropozytywnych. Spośród 34,0\% respondentów o pozytywnym nastawieniu do pacjentów seropozytywnych, $24,7 \%$ pielęgniarek wiedziało o istnieniu procedury poekspozycyjnej w swoim miejscu pracy, 4,1\% twierdziło, że w ich miejscu pracy nie ma takiej procedury, a 5,2\% pielęgniarek nie wiedziało czy taka procedura istnieje. Spośród 46,4\% respondentów o obojętnym nastawieniu do pacjentów seropozytywnych $36,1 \%$ pielęgniarek wiedziało o istnieniu procedury poekspozycyjnej w swoim miejscu pracy, 6,2\% twierdziło, że $\mathrm{w}$ ich miejscu pracy nie ma takiej procedury, 4,1\% pielęgniarek nie wiedziało czy taka procedura istnieje. Spośród 19,6\% respondentów $\mathrm{z}$ negatywnym nastawieniem, $7,2 \%$ wiedziało o istnieniu procedury poekspozycyjnej w swoim miejscu pracy, następne $7,2 \%$ pielęgniarek twierdziło, że w ich pracy nie ma takiej procedury, 5,2\% nie wiedziało, czy taka procedura się znajduje.

Analizując zależności pomiędzy wiedzą pielęgniarek na temat HIV/AIDS a nastawieniem do pacjentów seropozytywnych, z obliczeń otrzymano wartość statystyki $\chi^{2}=13,689$. Natomiast dla przyjętego poziomu istotności $\alpha=0,05$ i dla 6 stopni swobody odczytana z tablicy rozkładu $\chi^{2}$ wartość krytyczna wynosiła $\chi_{\alpha}{ }^{2}=12,592$. W związku z tym, iż wartość $\chi^{2}$ zawierała się w obszarze krytycznym, gdyż $\chi^{2} \geq \chi_{\alpha}^{2}$ to hipotezę $\mathrm{H}_{0}$ o niezależności należało odrzucić. Oznaczało to występowanie zależności między poziomem wiedzy pielęgniarek na temat HIV/AIDS a ich nastawieniem do pacjentów seropozytywnych.

Postawy pielęgniarek wobec pacjentów HIV(+), są dość odmienne w stosunku do ich wiedzy, która prezentowana jest na poziomie średnim. Większość badanych unikała kontaktów z pacjentami, odczuwała strach, co może świadczyć o poczuciu zagrożenia zakaże- 
niem HIV. Tylko 14,4\% respondentów odpowiedziało bezbłędnie na 12 pytań weryfikujących posiadanie wiedzy na temat HIV/AIDS, z czego 4,1\% deklarowało pozytywne nastawienie do osób seropozytywnych, $6,2 \%$ obojętne, 4,1\% negatywne. $37,1 \%$ respondentów popełniło od 1 do 3 błędów, gdzie 11,4\% deklarowało pozytywne nastawienie, $21,6 \%$ obojętne oraz $4,1 \%$ negatywne. $\mathrm{Z}$ kolei $37,2 \%$ respondentów popełniło od 4 do 6 błędów, spośród tej grupy 14,4\% deklarowało pozytywne nastawienie, $14,5 \%$ nastawienie obojętne, negatywne $8,3 \%$. Natomiast $11,3 \%$ respondentów popełniło 7 i więcej błędów na 12 możliwych, w tej grupie 4,1\% pielęgniarek deklarowało pozytywne nastawienie, $4,1 \%$ obojętne oraz 3,1\% negatywne.

Analizując związki pomiędzy wiedzą pielęgniarek na temat zasad kodeksu etyki zawodowej a ograniczaniem do minimum kontaktów z pacjentami seropozytywnymi, z obliczeń otrzymano wartość statystyki $\chi^{2}=10,557$. Natomiast dla przyjętego poziomu istotności $\alpha$ $=0,05$ i dla 4 stopni swobody odczytana z tablicy rozkładu $\chi^{2}$ wartość krytyczna wynosiła $\chi_{\alpha}^{2}=9,488$. W związku z tym, iż wartość $\chi^{2}$ zawierała się w obszarze krytycznym, gdyż $\chi^{2} \geq \chi_{\alpha}{ }^{2}$ to hipotezę $\mathrm{H}_{0} \mathrm{O}$ niezależności należało odrzucić. Oznaczało to występowanie zależności między wiedzą pielęgniarek na temat zasad kodeksu etyki zawodowej a ich ograniczaniem do minimum kontaktu z pacjentami seropozytywnymi. Spośród 29,9\% respondentów oceniających wysoko swoją wiedzę na temat zasad kodeksu etyki zawodowej 10,3\% pielęgniarek ograniczało do minimum kontakty z pacjentami seropozytywnymi w pracy zawodowej, nie ograniczało kontaktów 10,5\% oraz 9,3\% miało trudność w określeniu jednoznacznej odpowiedzi. Spośród $53,6 \%$ respondentów oceniających swoją wiedzę etyczną w stopniu średnim 36,1\% ograniczało do minimum kontakty, 8,2\% nie ograniczało kontaktów oraz 9,3\% miało trudność w określeniu jednoznacznej odpowiedzi. W stopniu niskim swoją wiedzę w zakresie etyki zawodowej oceniło 16,5\% pielęgniarek, spośród których 6,2\% ograniczało do minimum kontaktów z pacjentami zakażonymi wirusem HIV, 
6,2\% nie ograniczało kontaktów, a 4,1\% miało trudność w określeniu jednoznacznej odpowiedzi.

\section{Dyskusja}

W skali globalnej, epidemia HIV na świecie ustabilizowała się, choć obserwuje się bardzo wysoki poziom nowych zakażeń HIV i zgonów z powodu AIDS. W Polsce od czasu wykrycia pierwszego przypadku w roku 1985 do 31 grudnia 2013 roku według danych epidemiologicznych Państwowego Zakładu Higieny, zarejestrowano 17565 zakażonych. Ministerstwo Zdrowia szacuje, że w Polsce rzeczywista liczba zakażeń jest znacznie większa i może wynosić nawet do 35 000. Dziś wydawałoby się, że społeczeństwo wielu krajów solidaryzuje się z osobami żyjącymi z HIV, a pracownicy ochrony zdrowia są odpowiednio przeszkoleni i posiadają wiedzę o metodach pracy z pacjentami HIV dodatnimi. Niestety są to często stwarzane pozory, a przecież prewencja, która ma za zadanie przekazywanie informacji na ten temat, jest główną bronią w walce z HIV i AIDS. Ważne jest aby edukacja oparta była na naukowych faktach a nie mitach, które mogłyby się przyczyniać do prezentowania postaw nacechowanych nietolerancją i brakiem życzliwości wobec tych ludzi.

Postawy pielęgniarek studiujących na kieruku pielęgniarstwo studia II stopnia na WSHE we Włocławku, pracujących w różnych placówkach ochrony zdrowia, wobec pacjentów zarażonych wirusem HIV i chorych na AIDS, są umiarkowanie pozytywne, ponieważ $34,0 \%$ pielęgniarek deklarowało pozytywne nastawienie do osób seropozytywnych, 46,4\% respondentów była ustosunkowana obojętnie, negatywne nastawienie występowało tylko, a właściwie aż u 19,6\% badanych. Natomiast w badaniach Karwata i Ordakowskiego, przeprowadzonych wśród 76 osobowego personelu pielęgniarskiego nie pracującego $\mathrm{w}$ klinikach zakaźnych uzyskano wyniki, bardzo odmienne od badań własnych prezentowanych powyżej, gdyż $77,6 \%$ respondentów miało 
negatywny stosunek do osób seropozytywnych, $21,1 \%$ pozytywny a obojętny tylko $1,3 \%$ [8].

W badaniach własnych, aż $52,6 \%$ pielęgniarek przyznało się, że ograniczało do minimum kontakty $\mathrm{z}$ pacjentami seropozytywnymi, $24,7 \%$ nie ograniczało kontaktów, a 22,7\% była nie zdecydowana jaką odpowiedź wybrać. $\mathrm{W}$ badaniach Karwata i Ordakowskiego 67,1\% respondentów zapewniało wystarczającą opiekę pielęgniarską nad osobami zakażonymi wirusem HIV i chorymi na AIDS, a 32,9\% nie zapewniało wystarczającej opieki osobom kojarzonym z HIV [8].

$\mathrm{Z}$ kolei $\mathrm{z}$ badań Cybulskiego i Pawłowskiej, przeprowadzonych wśród studentów Uniwersytetu Medycznego w Białymstoku, uzyskano wyniki przeciwstawne do wyników własnych, ponieważ 55\% studentów uznało, że najskuteczniejszą obroną przed zakażeniem HIV jest unikanie wszelkich kontaktów z zakażonymi. Odpowiedzi „raczej nie” udzieliło 30,3\% respondentów [9].

Jeśli chodzi o uzasadnioną przyczynę odmowy udzielenia medycznej pomocy osobie seropozytywnej, to w badaniach własnych zdecydowana większość pielęgniarek - 84,5\% (82) uważała, że nie ma takiej przyczyny, która byłaby usprawiedliwieniem odmowy udzielenia medycznej pomocy osobie zakażonej wirusem HIV, ale $15,5 \%$, uważała, że takie powody istnieją, tłumacząc je brakiem środków ochrony indywidualnej, agresywnością pacjenta, niewiedzą ze strony personelu medycznego. Natomiast w badaniach CiastońPrzecławskiej, aż 50\% pielęgniarek uważało, że istnieją uzasadnione przyczyny odmowy udzielenia medycznej pomocy, wskazując na brak odpowiednich środków zabezpieczających a 40\% pielęgniarek wskazało na silną obawę przed zakażeniem i niedostatek wiedzy [10].

Z badań własnych wynikało, że doświadczenie zawodowe z pacjentami seropozytywnymi posiadała mała grupa respondentów, tylko 37,1\%, a 62,9\% pielęgniarek pomimo przeważającej większości długiego stażu zawodowego, nie miało w swojej pracy doświadczenia z osobami HIV (+). Również badania Karwata i Ordakowskiego 
świadczą o małym doświadczeniu personelu pielęgniarskiego z osobami zakażonymi wirusem HIV[20]. Z badań Szymon i Gotlib przeprowadzonych wśród 620 studentów kierunku pielęgniarstwo Uniwersytetu Medycznego w Warszawie wynika, że 76\% badanych $\mathrm{w}$ dotychczasowej pracy zawodowej miała już kontakt $\mathrm{z}$ osobą zakażoną [11].

Ponad połowa - 64\% tej samej grupy respondentów Uniwersytetu Warszawskiego deklarowała, że odczuwa niepokój podczas wykonywania zabiegów osobie, która jest zakażona. W badaniach własnych $32,0 \%$ badanych pielęgniarek wyznało, że odczuwa strach podczas kontaktu z pacjentami zarażonymi wirusem HIV, 29,9\% raczej odczuwa strach, co razem stanowi bardzo zbliżony wynik z uzyskanym przez Szymon i Gotlib [11].

Według wyników badań własnych większość respondentów, czyli 59,8\% oceniło swoją wiedzę w zakresie HIV/AIDS na poziomie średnim, 32,0\% na poziomie wysokim i 8,2\% na poziomie niskim. W badaniach Krajewskiej-Kułak i Van DammeOstapowicz, dotyczących wiedzy studentów Uniwersytetu Medycznego w Białymstoku na temat chorób zakaźnych, 42,2\% respondentów uznało zakres wiedzy za raczej pozytywny. Jedynie co czwarta osoba uważała, że wiedza studentów jest niewystarczająca[12]. Natomiast badania Cybulskiego i Pawłowskiej, przeprowadzone wśród studentów Uniwersytetu Medycznegow Białymstoku, dotyczące samooceny wiedzy na temat HIV/AIDS, wypadły zdecydowanie inaczej od badań własnych. Większość badanych $(77,3 \%)$ oceniło swój poziom wiedzy raczej wysoko, a tylko 20\% deklarowało raczej niski poziom [9].

Badania własne potwierdziły, że samoocena wiedzy respondentów pokrywa się z posiadaną wiedzą i również jest na średnim poziomie. Odpowiedzi na 12 pytań weryfikujących elementarną wiedzę respondentów na temat HIV/AIDS, sprawdzono i utworzono cztery grupy. W pierwszej, z wszystkimi odpowiedziami prawidłowymi, znalazło się tylko 14,5\% pielęgniarek. W drugiej grupie, gdzie 
popełniono od 1 do 3 błędów- 37,1\% respondentów. W trzeciej, z błędnymi odpowiedziami od 4 do 6, znalazło się 37,1\% pielęgniarek a w ostatniej, 7 i więcej błędów popełniło 14,3\%. Podobnie w badaniach Karwata i Ordakowskiego, większość respondentów - 75\% ma średni poziom wiedzy na temat HIV/AIDS[20]. Natomiast $w$ badaniach Cybulskiego i Pawłowskiej, większość respondentów charakteryzowało się wysokim poziomem wiedzy na temat podstawowych zagadnień dotyczących HIV/AIDS [9].

W ostatnich latach w Polsce, liczba nowo rozpoznanych zakażeń HIV rośnie. W badaniach własnych prawidłowo na to pytanie odpowiedziało 46,4\% pielęgniarek, 36,1\% odpowiedziało, że zakażenia HIV utrzymują się na tym samym poziomie, natomiast $17,5 \%$ uważało, że liczba maleje. Jeśli chodzi o postrzeganie istotności problemu HIV/AIDS w Polsce, to w badaniach Cybulskiego i Pawłowskiej, ponad 59\% ankietowanych studentów uznało, że jest to istotny problem epidemiologiczny i społeczny, ale niespełna $40 \%$ stwierdziło, że raczej nie jest to poważny problem polskiego społeczeństwa [9].

W badaniach własnych odsetek respondentów, który uczestniczył w szkoleniach specjalistycznych na temat HIV/AIDS kilka razy, wynosił 20,6\%, jeden raz brało w nich udział $36,1 \%$ pielęgniarek, a 43,3\% nigdy nie było na tego typu szkoleniu. Natomiast w badaniach Ciastoń-Przecławskiej, w ostatnich dwóch latach osobiście uczestniczyło w szkoleniach 54,1\% pielęgniarek [10].

Badania własne wykazały, iż swoje miejsce pracy pod względem ryzyka zakażenia HIV, respondenci w 44,3\% ocenili jako miejsce wysokiego ryzyka, 40,2\% jako miejsce średniego ryzyka oraz $15,5 \%$ jako miejsce niskiego ryzyka. Podobne wyniki w tej kwestii uzyskali Karwat i Ordakowski [8].

Jeżeli chodzi o ocenę swojego miejsca pracy pod względem wyposażenia w środki ochrony indywidualnej, 26,8\% respondentów oceniło ten aspekt w szerokim zakresie, większość 52,6\% oceniło wyposażenie w średnim zakresie, 20,6\% oceniło w niewielkim zakresie. Natomiast w badaniach Karwata i Ordakowskiego żaden 
z respondentów nie uznał, że zakład pracy w którym pracuje stosuje szeroki zakres działań ochrony pracownika, aż 48,7\% uważa, że zakład stosuje środki ochrony zdrowia pracownika $\mathrm{w}$ niewielkim zakresie [8].

Podsumowując wyniki badań własnych można stwierdzić, że poczucie zagrożenia i lęku przed zakażeniem HIV wśród badanych pielęgniarek studiujących na WSHE we Włocławku było dość wysokie. Można wnioskować, że główną przyczyną tego stanu może być, pomimo posiadanej wiedzy na średnim poziomie z zakresu HIV/AIDS, mała liczba odbytych przez respondentów, profesjonalnych szkoleń prowadzonych przez specjalistów posiadających wiedzę płynącą z własnego doświadczenia.

\section{Wnioski}

1. Z uzyskanych wyników badań oraz przeprowadzonych analiz wynikało, że tylko niespełna $20 \%$ badanych cechowało negatywne nastawienie wobec chorych seropozytywnych. Jednak blisko 50\% respondentów było ustosunkowanych obojętnie. Wynik ten budzi niepokój autorów, wskazując na rutynowe, schematyczne, formalne traktowanie pracy z osobami chorymi.

2. Daje się zauważyć pewną niekonsekwencję ze strony pielęgniarek, gdyż deklarowane przez większość pozytywne nastawienie do chorych nie pokrywało się z prezentowanymi zachowaniami. Zdecydowana większość respondentów stała jednak na stanowisku, iż należy informować w miejscu pracy/nauki o zakażeniu HIV, jednocześnie deklarując, że nie mogłaby pracować z koleżanką seropozytywną na tym samym odcinku.

3. Z uzyskanych badań oraz przeprowadzonych analiz wynikało, iż istnieje zależność pomiędzy wiekiem personelu pielęgniarskiego, stanem cywilnym, stażem pracy a postawą wobec pacjentów seropozytywnych. Nie dowiedziono takiej zależności 
między miejscem pracy i wyższymi kwalifikacjami personelu pielęgniarskiego a postawą wobec pacjentów seropozytywnych.

4. Badania dowiodły także zależności między stopniem wyposażenia stanowiska pracy w środki ochrony indywidualnej oraz w procedurą postępowania po ekspozycji zawodowej, a postawą pielęgniarek wobec pacjentów zakażonych wirusem HIV/chorych na AIDS.

5. Dowiedziono także istnienia zależności między posiadaną wiedzą a postawą wobec pacjentów seropozytywnych. Pielęgniarki uczestniczące w badaniu, w większości oceniły swoją wiedzę w zakresie HIV/AIDS na poziomie średnim.

6. Warto też zwrócić uwagę na fakt, że prawie połowa respondentów nigdy nie uczestniczyła w szkoleniach specjalistycznych na temat HIV/AIDS.

7. Szczegółowa analiza badań wykazała, że znajomość zasad etyki zawodowej nie w pełni przekłada się na właściwą postawę wobec chorych zarażonych HIV.

8. Zdecydowana większość pielęgniarek uczestniczących $\mathrm{w}$ badaniu uważała, że nie ma takiej przyczyny, która mogłaby być usprawiedliwieniem odmowy udzielenia medycznej pomocy osobie zakażonej wirusem HIV, ale pewna grupa pielęgniarek uważała, że takie powody istnieją. Za przyczynę nie udzielenia pomocy, podawano brak środków ochrony indywidualnej, agresywność pacjenta, niewiedzę personelu medycznego.

\section{Zalecenia dla praktyki pielęgniarskiej}

Pomimo, iż większość respondentów deklarowała pozytywne i obojętne nastawienie do pacjentów seropozytywnych, to jednak wyniki uzyskane $\mathrm{z}$ analizy prezentowanych $\mathrm{w}$ ankiecie zachowań pielęgniarek wobec tej grupy chorych budzą niepokój autorów. Można wnioskować, że główną przyczyną tego stanu może być nie tyle brak wiedzy, co zbyt mała liczba odbytych przez respondentów szkoleń 
prowadzonych przez profesjonalistów. Okresowe kontakty z kompetentnymi i doświadczonymi szkoleniowcami, mogą odegrać znaczącą rolę w kształtowaniu postaw i zachowań zarówno wśród pielęgniarek, jak i pozostałych pracowników ochrony zdrowia. Wykazana istotna zależność statystyczna pomiędzy postawą pielęgniarek wobec pacjentów zakażonych wirusem HIV/chorych na AIDS a wyposażeniem stanowiska pracy w środki ochrony indywidualnej oraz w procedura postępowania po ekspozycji zawodowej, potwierdza ważność istnienia procedur medycznych w ochronie zdrowia oraz konieczność przestrzegania ich podczas wykonywania codziennej pracy pielęgniarskiej. W celu unikania ekspozycji zawodowej podczas posługiwania się ostrymi narzędziami oraz przy kontaktach z płynami ustrojowymi, należy oprócz postępowania zgodnego z procedurami i standardami zawodowymi, również zachowywać spokój i szczególną ostrożność.

\section{Bibliografia/Bibliography:}

1. Gładysz A., Knysz B. Diagnostyka, profilaktyka i terapia zakażeń HIV/AIDS. Współczesne możliwości i problemy. Wydawnictwo Continuo, Wrocław 2009.

2. Grajcarek A. (red.) Jak zmniejszyć ryzyko zakażenia HIV w praktyce pielęgniarskiej. Poradnik dla pielęgniarek i położnych. Wydawnictwo Fundacji ad Vocem, Kraków 2010:9-173.

3. Kilańska D. Organizacje pielęgniarskie liderem zmian - droga do Dyrektywy 32/2010/UE. Stanowisko Polskiego Towarzystwa Pielęgniarskiego. Ogólnopolski Kongres Ekspozycji Zawodowej. Podsumowanie. Artykuły Rady Ekspertów Kongresu, Warszawa 2012:6-9.

4. Gańczak M. Szych Z. Postawy personelu medycznego wobec osób zakażonych HBV, HCV lub HIV pracujących w oddziałach zabiegowych oraz badania serologiczne pracowników. Medycyna Pracy. 2013; 64(5);639-647. 
5. Krajewska-Kułak E., Sierakowska M (red.) Pacjent podmiotem troski zespołu terapeutycznego. Postawy i obawy pielęgniarek oddziałów zabiegowych w woj. Zachodniopomorskim wobec zawodowego ryzyka zakażenia wirusem HIV. Akademia Medyczna, Białystok 2005: 373-381.

6. Gladysz A (red.) Zakażenia HIV/AIDS, poradnik dla lekarzy praktyków. Wydawnictwo Continuo, Wrocław 2007: 9-187.

7. Zielazny P., Wojtecka A. HIV/AIDS w wybranych kulturach judeochrześcijańskich. Medycyna Ogólna i Nauki o Zdrowiu. 2013; 19(3): 267-271.

8. Karwat B., Ordakowski M. Stosunek personelu pielęgniarskiego nie pracującego w klinikach zakaźnych do osób żyjących z HIV i chorych na AIDS. Stowarzyszenie na rzecz Rozwoju Społecznego „Stricte”, Szczecin 2007.

9. Cybulski M., Pawłowska M. Wiedza na temat zakażeń wirusem HIV oraz postawy wobec osób z HIV/AIDS wśród studentów kierunku Zdrowie Publiczne Uniwersytetu Medycznego w Białymstoku. Problemy Higieny i Epidemiologii. 2012; 3 :618-622.

10. Ciastoń-Przecławska E. Lekarze, pielęgniarki i pracownicy służb socjalnych wobec wybranych zagadnień HIV i AIDS. Krajowe Centrum ds. AIDS, Warszawa 2003.

11. Szymon A., Gotlib B. Próba oceny wiedzy studentów Pielęgniarstwa na temat wirusa HIV i zagadnień dotyczących AIDS. Pielęgniarstwo XXI wieku 2013 (42): 27-32.

12. Krajewska-Kułak E., Van Damme - Ostapowicz K. Analiza wiedzy studentów pielęgniarstwa w województwie podlaskim na temat chorób zakaźnych i zakażeń szpitalnych. Problemy Higieny i Epidemiologii. 2009; 90(4):613-620. 
